\title{
Water risk assessment for river basins in China based on WWF water risk assessment tools
}

\author{
NA WEI, YAQIN QIU, HONG GAN, CUNWEN NIU, JIAJIA LIU, YONGDE GAN \\ \& NA ZHOU \\ State Key Laboratory of Simulation and Regulation of Water Cycle in River Basin, China Institute of Water Resources \\ and Hydropower Research, 1 Yu-Yuan-Tan South Road, Beijing 100038, China \\ 844787598@qq.com
}

\begin{abstract}
Water resource problems, one of the most important environmental and socio-economic issues, have been a common concern worldwide in recent years. Water resource risks are attracting more and more attention from the international community and national governments. Given the current situations of water resources and the water environment, and the characteristics of water resources management and information statistics of China, this paper establishes an index system for water risk assessment in river basins of China based on the index system of water risk assessment proposed by the World Wide Fund For Nature (WWF) and German Investment and Development Co., Ltd (DEG). The new system is more suitable for Chinese national conditions and endorses the international assessment index. A variety of factors are considered to determine the critical values of classification for each index, and the indexes are graded by means of 5-grade and 5-score scales; the weights and calculation methods of some indexes are adjusted, with the remaining indexes adopting the method of WWF. The Weighted Comprehensive Index Summation Process is adopted to calculate the integrated assessment score of the river basin. The method is applied to the Haihe River basin in China. The assessment shows that the method can accurately reflect the water risk level of different river basins. Finally, the paper discusses the continuing problems in water risk assessment and points out the research required to provide a reference for further study in this field.
\end{abstract}

Key words water risk assessment; assessment index; index weights; assessment method; Haihe River Basin; problems and prospects

\section{INTRODUCTION}

Being a fundamental natural resource and strategic economic resource, intensive and relentless exploitation of water resources has resulted in a series of issues which directly affect socioeconomic development and the ecological environment balance. The water resources crisis is an unavoidable challenge in the water shortage countries, including China. The status of water resources in China is not optimistic; the problems of water shortage and water pollution erupted fiercely in the last decade, water quality and water quantity are both deep in crisis. Implementing risk management of water resources aims to improve the management level of water resources, the effective ways and development trends to deal with the problem. Therefore, the key point is to find a method for evaluating the water risk to economic society and to establish development plans to maintain sustainable water resources development and ecological protection.

International research on risk problems started during the 1930s-1940s. In the 1950s, the United States founded special research institutes to study the risk and reliability of aerospace, nuclear field and electronic systems. The application of risk research in water resources systems began at the end of the 1950s and increasing numbers of scholars have studied/been concerned the water resources system risk analysis of in the last 20-30 years. Scholars from China and elsewhere have undertaken much water risk research; water shortage and water pollution was discussed by Jinno (1995), Ruan et al. (2005), Ghosh and Mujumdar (2006), Ma and Wang (2008), Zhang et al. (2011).

Study on a larger-scale of standardized water risk assessment is seldom seen. In 2012 the World Wide Fund for Nature (WWF), together with the German Investment and Development Co., Ltd (DEG), produced a method of water risk assessment, based on an evaluation index system including the national level, river basin level and enterprise level. This method has been applied in 85 countries, and about 25000 enterprises. According to the evaluation index systems at the river basin level introduced by WWF, water risk assessment of China needs to link up with an international assessment index system, so making the results comparable worldwide. Also, water risk assessment needs to consider the national situation, such as water resources characteristics and information statistics modes, to make the assessment more feasible and results more credible. 
Therefore, this paper makes some adjustments to the assessment indexes and weights proposed by WWF, details the concepts behind some indexes and calculation methods, and puts forward a research method for water risk assessment in river basins in China, which is more suitable for the Chinese national situation and is able to reflect the true facts of a given basin.

\section{WATER RISK ASSESSMENT FRAMEWORK}

The definition of risk was discussed by Frank (1921), Ye and Yi (2000) and Ding and Fang (2001), Ben (2010). WWF and DWG put forward the concept of water risk, that is, the potential waterrelated risk caused by the behaviour of natural factors and human activities. WWF put forward 19 assessment indexes for water risk: 12 are physical risk assessment indexes, four are regulatory risk assessment indexes and three are reputational risk assessment indexes. Physical risk refers to the quantity (scarcity and flooding) and quality (pollution) risk in the basin due to human activities and natural factors; Regulatory risk refers to the enforcement of water related management by government, including the coherence of regulations, the ability and fairness of enforcement of rules, etc. Reputational risk refers to the potential risk from negative public opinion, which is mainly reflected in water awareness promotion and education. The water risk evaluation index system for river basins in China was built according to the consistency and comparability principles, and considering the characteristics of water resources management and information statistics in China,. The number of water risk assessment indexes was reduced to 16: 10 are physical risk evaluation indexes, four are the regulatory risk evaluation indexes, and two are reputational risk evaluation indexes. These indexes characterize the water risk in terms of water quantity, water quality, hydropower, ecological environment, etc., take into account the effect of socio-economics and management, and comprehensively consider government functions and supervision by social media. The concepts and instructions for adjustment of the various indexes are described below.

\section{Physical risk indexes adjustment}

After adjustment, Physical risk assessment includes 10 indexes of four main categories: water resource shortage, water pollution discharge, aquatic ecosystem health and hydroelectric power dependence. The concept and instructions of adjustment for the indexes are introduced in Table 1. The indexes of "Annual average monthly water scarcity (water footprint)", "Number of months per year water scarcity exceeding $100 \%$ in this river basin" and "Maximum rate of month water scarcity" were abandoned; "The annual average yearly water scarcity" is adopted to reflect the water scarcity in the river basin. The concept of "Impact of climate change", "Influence of drought", "Estimated occurrence of floods", "Water pollution discharge", and "Vulnerability of water ecosystems" are redefined with improvement of calculation methods of some indexes.

Among the physical risk assessment indexes, Water resources scarcity can be reflected by the unevenness of water resources distribution in both time and space, the frequency of extreme events, conflicts between supply and demand, and climate change. Ecosystem health can be reflected by freshwater biodiversity, water ecosystem security, safe drinking water and social activities pollution.

\section{Regulatory risk indexes adjustment}

Regulatory risk assessment includes four indexes. Table 2 describes the index concepts and instructions for adjustment.

\section{Reputational risk indexes adjustment}

There are 3 Reputational risk assessment indexes. Because of the influence of cultural differences, religion, language and ideology on international media, their perspective on water issues is different. This research adopts critical reports in the domestic media on possible water issues instead of reports in the local/national and the national/global media (Table 3 ). 
Table 1 Physical risk assessment indexes.

\begin{tabular}{|c|c|c|}
\hline WWF indexes & Instructions for Chinese indexes system & The meaning of indexes \\
\hline \multicolumn{3}{|c|}{ WATER RESOURCES SCARCITY } \\
\hline $\begin{array}{l}\text { Annual average } \\
\text { monthly water scarcity } \\
\text { (water footprint) }\end{array}$ & \multirow{3}{*}{$\begin{array}{l}\text { These } 3 \text { indexes are reasonable to assess water } \\
\text { risk of enterprises and industries, but not } \\
\text { suitable for large-scale. The annual average } \\
\text { yearly water scarcity is more reasonable to } \\
\text { assess water risk in large-scale areas. }\end{array}$} & $\begin{array}{l}\text { Water shortage ratio is the ratio of the difference of } \\
\text { total water demand and available with total water } \\
\text { demand. }\end{array}$ \\
\hline $\begin{array}{l}\text { Number of months per } \\
\text { year water scarcity } \\
\text { exceeding } 100 \% \text { in this } \\
\text { river basin }\end{array}$ & & not adopted \\
\hline $\begin{array}{l}\text { Maximum rate of } \\
\text { month water scarcity }\end{array}$ & & not adopted \\
\hline $\begin{array}{l}\text { Impact of climate } \\
\text { change }\end{array}$ & $\begin{array}{l}\text { To match with other indexes, this index adopts } \\
\text { the temperature change over the past } 30 \text { years. }\end{array}$ & $\begin{array}{l}\text { Through calculating regional annual temperature } \\
\text { change to calculate impact degree of climate change. }\end{array}$ \\
\hline $\begin{array}{l}\text { Influence of drought } \\
(2008-2010)\end{array}$ & $\begin{array}{l}\text { Using indexes of WWF, calculating the } \\
\text { influence ranges of severe drought and heavy } \\
\text { drought happened from } 2008 \text { to } 2010\end{array}$ & $\begin{array}{l}\text { The paper mainly studies meteorological drought and } \\
\text { adopts the precipitation anomaly percentage to divide } \\
\text { drought level. }\end{array}$ \\
\hline $\begin{array}{l}\text { Estimated occurrence } \\
\text { of floods (1985-2005) }\end{array}$ & $\begin{array}{l}\text { Using indexes of WWF, calculating the number } \\
\text { of large basin floods happened from } 1985 \text { to } \\
2005\end{array}$ & $\begin{array}{l}\text { The research studies the large basin flood (return } \\
\text { period larger than or equal to } 20 \text { years) and catas- } \\
\text { trophic flood (return period larger than or equal to } 50 \\
\text { years) }\end{array}$ \\
\hline \multicolumn{3}{|c|}{ WATER POLLUTION DISCHARGE } \\
\hline $\begin{array}{l}\text { General situation of } \\
\text { water pollution }\end{array}$ & $\begin{array}{l}\text { The assessment selects } 5 \text { indexes of } 4 \text { categories } \\
\text { to characterize the pollution discharge, and then } \\
\text { assess water pollution discharge after analysing } \\
\text { each value membership grade. }\end{array}$ & $\begin{array}{l}\text { Assessment indexes: waste water discharge index, the } \\
\text { pollution discharge index (COD and ammonia), } \\
\text { sewage treatment index and river water body pollution } \\
\text { indexes }\end{array}$ \\
\hline \multicolumn{3}{|l|}{ ECOSYSTEM HEALTH } \\
\hline $\begin{array}{l}\text { Freshwater } \\
\text { biodiversity }\end{array}$ & Use indexes of WWF & $\begin{array}{l}\text { The research adopts the results in Threat to Global } \\
\text { Human Security and Freshwater Biodiversity by C. J. } \\
\text { Vorosmarty published in Nature in } 2010 \text {. }\end{array}$ \\
\hline $\begin{array}{l}\text { Vulnerability of water } \\
\text { ecosystems }\end{array}$ & $\begin{array}{l}\text { For large-scale area aquatic ecosystem } \\
\text { vulnerability, China usually adopts general } \\
\text { situation of water ecosystem security to } \\
\text { evaluate. }\end{array}$ & $\begin{array}{l}\text { Assessment indexes: drought index, the proportion of } \\
\text { water use quantity for eco-environmental in the river, } \\
\text { deficit rate of ecological water and the ratio of } \\
\text { excessively exploited groundwater }\end{array}$ \\
\hline $\begin{array}{l}\text { Access to safe drinking } \\
\text { water }\end{array}$ & Use indexes of WWF & $\begin{array}{l}\text { The research adopts data come from } 2011 \text { China } \\
\text { Statistical Yearbook and } 2011 \text { China Water } \\
\text { Conservancy Statistical Yearbook. }\end{array}$ \\
\hline $\begin{array}{l}\text { Access to improved } \\
\text { sanitation }\end{array}$ & Use indexes of WWF & $\begin{array}{l}\text { The research adopts data in } 2011 \text { Health Statistics } \\
\text { Yearbook and } 2011 \text { China Statistics Yearbook. }\end{array}$ \\
\hline \multicolumn{3}{|c|}{ DEPENDENCY ON HYDROELECTRIC POWER } \\
\hline $\begin{array}{l}\text { Dependency on } \\
\text { hydroelectric power }\end{array}$ & Use indexes of WWF & $\begin{array}{l}\text { The hydroelectric dependency is calculated by the ratio } \\
\text { of hydropower generating capacity to the total } \\
\text { generating capacity. }\end{array}$ \\
\hline
\end{tabular}

Table 2 Regulatory risk assessment indexes.

\begin{tabular}{lll}
\hline WWF indexes & $\begin{array}{l}\text { Instructions for China } \\
\text { indexes system }\end{array}$ & The meaning of indexes \\
$\begin{array}{l}\text { Water strategy of (local, national } \\
\text { and upstream) governments }\end{array}$ & Use indexes of WWF & $\begin{array}{l}\text { The research collects water strategy of government (local, national } \\
\text { and upstream), including flood and drought planning, to evaluate. } \\
\begin{array}{l}\text { Sophistication and clarity of } \\
\text { water-related law and regulation } \\
\text { system }\end{array}\end{array}$ \\
$\begin{array}{l}\text { Enforcement of water-related } \\
\text { legal framework }\end{array}$ & Use indexes of WWF & $\begin{array}{l}\text { The research is conducted by means of analysing the water-related } \\
\text { laws, regulations, government regulations, normative documents, } \\
\text { policy interpretation, etc. collected in different basins. } \\
\text { The research is conducted in the aspect of capital input, regulation } \\
\text { coverage as well as governance and protection. The main statistical } \\
\text { indexes contain the investment in water conservancy, investment in } \\
\text { sewage treatment, quantity of monitored water functional zones, } \\
\text { quantity of monitored provincial section and treatment rate of } \\
\text { domestic sewage, etc. }\end{array}$ \\
$\begin{array}{l}\text { Official forum or platform in } \\
\text { which stakeholders come } \\
\text { together to discuss water-related } \\
\text { issues of the basin }\end{array}$ & Use indexes of WWF & $\begin{array}{l}\text { The index assessment is analysed by means of investigating the } \\
\text { water conservancy forum of each basin, online interview, online } \\
\text { petition and supervision complaint, etc. }\end{array}$ \\
\hline
\end{tabular}


Table 3 Reputational risk assessment indexes

\begin{tabular}{lll}
\hline Indexes of WWF & $\begin{array}{l}\text { Instructions of China indexes system } \\
\text { adjustment }\end{array}$ & The meaning of indexes \\
\hline $\begin{array}{l}\text { Cultural and/or religious importance of } \\
\text { local water sources }\end{array}$ & Use indexes of WWF & $\begin{array}{l}\text { The research adopted construction of } \\
\text { water culture, Chinese concerning about } \\
\text { protection and conservation of water } \\
\text { resources to evaluate. }\end{array}$ \\
$\begin{array}{l}\text { Local/national media critical report on } \\
\text { possible water issues }\end{array}$ & $\begin{array}{l}\text { Domestic media critical report on possible } \\
\text { water issues }\end{array}$ & $\begin{array}{l}\text { The research group collects the reports on } \\
\text { water events in paper media, internet } \\
\text { media to evaluate }\end{array}$ \\
\hline possible water issues
\end{tabular}

\section{Weight adjustment}

Considering the various factors that each index influences, each index is given a certain weight. Based on the weights given by WWF, the weights of the physical risk, regulatory risk and reputational risk are 55\%, 35\% and 10\%, respectively. The subtype of each type has a sub weight. The weights of some indexes were readjusted accordingly from the WWF values (Table 4). In physical risk, the weights of the internal index of the risk of water resources scarcity were readjusted. In reputational risk, as a result of combination of the original indexes, the weight for domestic media critical reports on possible water issues was changed to $85 \%$.

\section{Evaluation method}

A variety of factors were considered to determine the critical values of classification for each index; the indexes were graded by means of a 5-grade and 5-score scale. Using the method given by WWF, the Weighted Comprehensive Index Summation Process is adopted to reflect the degree of the water risk in the region. The calculation is as follows:

$$
R=\sum_{i=1}^{n} f_{i} \times w_{i}
$$

$R$ represents the water risk evaluation grade; $f_{i}$ represents the score of each evaluation index; and $w_{i}$ represents the weight coefficient of relative water risk for each index. The smaller the calculation result is, the smaller the degree of water risk and vice versa. The values range between 0 and 5.

\section{CASE STUDY}

Haihe River basin is the most seriously water-deficient area among the 10 Chinese primary water resources areas, with water per capita less than $300 \mathrm{~m}^{3}$. The total catchment area is $3.18 \times 10^{5} \mathrm{~km}^{2}$, the multiyear average rainfall is $535 \mathrm{~mm}$; water resource amount is $3.7 \times 10^{10} \mathrm{~m}^{3}$ including annual runoff of $2.16 \times 10^{5} \mathrm{~m}^{3}$. Water risk in Haihe basin is assessed using the above theory. The research result of for Haihe basin is shown in the last column of Table 4.

The risk grade of Haihe basin is class III, that is, a moderate risk area. The physical risk has a large influence on the water risk, $69 \%$; the next in importance is regulatory risk, $20 \%$. The score for physical risk is 3.59 , the risk grade is class IV, that is, high risk. The contribution rate of water resources scarcity is relatively large, $53 \%$. The score for regulatory risk is 1.54 , and the risk grade is class II, that is, low risk. The contribution rate of enforcement of water related legal framework is relatively large at $35 \%$. The score for reputational risk is 3.53 and the risk grade is class IV, that is, high risk. The contribution of domestic media critical reports on possible water issues is relatively large, $77 \%$. The assessment result reflects the high intensity of human activities in Haihe basin. Measures must be taken to face the problems of water shortage, contradiction between the supply and requirement, water pollution and degeneration of ecological environment. 
Table 4 Index weights for water risk assessment, and assessment for Haihe River basin.

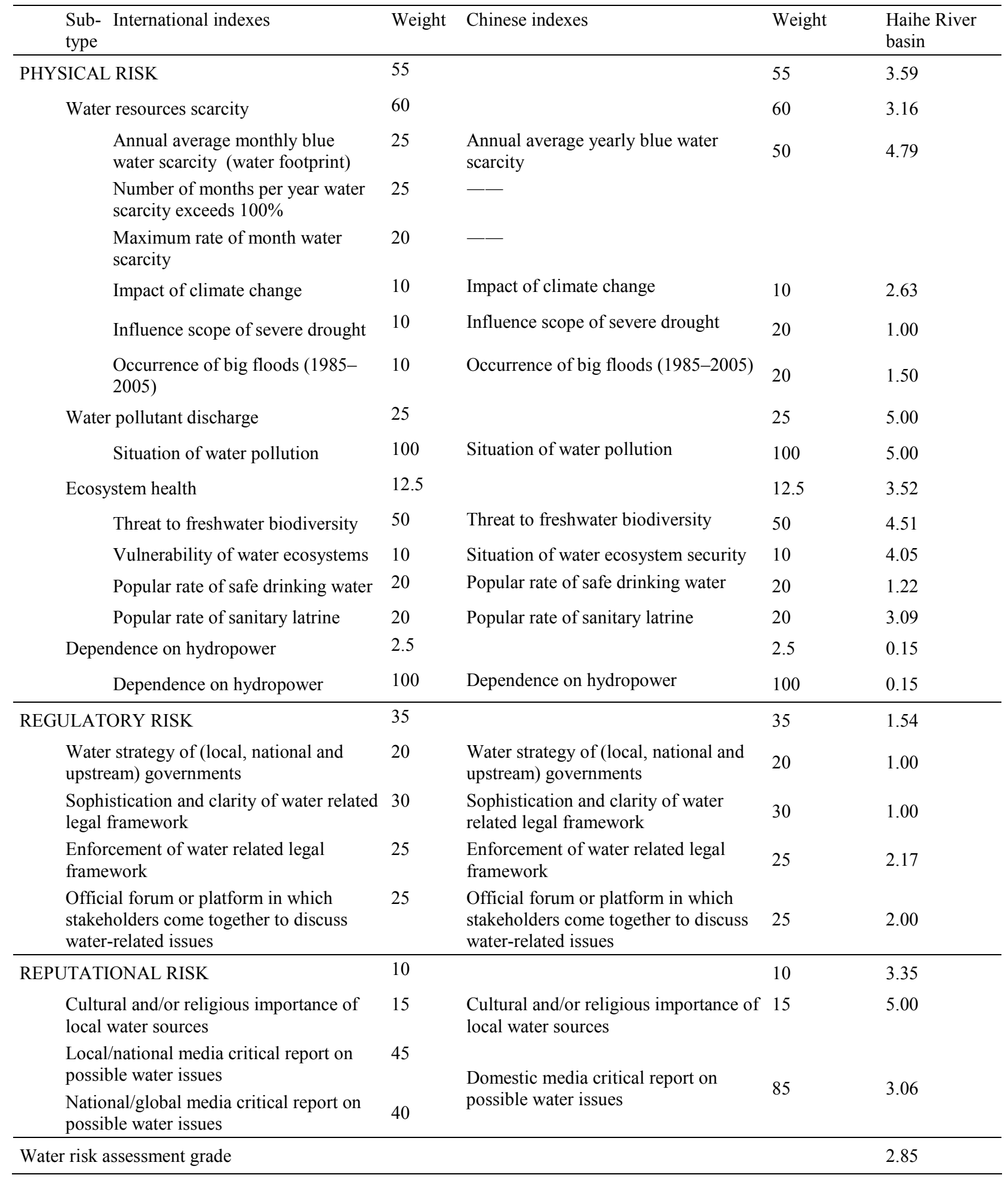

\section{CONCLUSION}

After adjustment of the system of indexes and weights developed by WWF, the paper establishes a new indexing system and method for water risk assessment in river basins in China, which provides reference information for decision-makers. However, there are still some aspects that need to be detailed fully and improved: 
1. Make further analyses of the science, rationality, adaptation and practicality of the water risk assessment index. There are a great many influencing factors in water risk assessment, thus it is imperative to perfect the water risk assessment index system and the computational method of the related indexes.

2. It is necessary to combine water risk assessment in river basins with enterprise risk assessment of the key industries to assist micro-decisions in the basin and micro-decisions for enterprise, which provide advice for industrial adjustment and strategic planning of the river basin or region.

3. Making water risk assessments regularly is required for dynamic water resources management and also research on policy analysis to mitigate water risk. Deep analysis of the causes of water risk, understanding of the relationship between water risk and water use patterns, economic development, economic structural adjustment and significant national planning, allow the proposal of the political suggestions to solve water risk so as to facilitate water risk management of a given basin.

Acknowledgements The research received financial support from the special fund project of public welfare of Ministry of Water Resources (201301001), the Nature Science Foundation of China (51021066, 50939006, 51209224, 51279210), and the Project of State Key Laboratory of Simulation and Regulation of Water Cycle in River Basin (2013ZY02, 2013QN02).

\section{REFERENCES}

WWF and DEG (2011) Assessing water risk-A practical approach for financial institutions. WWF and DEG report.

Ben, Z. Q. (2010) Research on methods and application for food security risk assessment. Chinese Rural Health Service Administration 30(2), 132-134 (in Chinese).

Ding, Y. M. and Fang, F. K. (2001) Analysis of concept of risk. Journal of System Engineering 16(5), $402-406$ (in Chinese).

Frank, K. (1921) Risk, Uncertainty and Profit. Boston: Houghton Mifflin.

Ghosh, S. and Mujumdar, P. P. (2006) Risk minimization in water quality control problems of a river system. Advances in Water Resources 29(3), 458-470.

Jinno, K. (1995) Risk assessment of water supply system during drought. Water Resources Development 11(2), 189-205.

Ma, L. and Wang, D. X. (2008) The distribution of water shortage risk and its countermeasures in China. Journal of China Institute of Water Resources and Hydropower Research 6(2), 131-143 (in Chinese).

Ruan, B. Q. and Han, Y. P., et al. (2005) Fuzzy comprehensive assessment of water shortage risk. Journal of Hydraulic Engineering 36(8), 906-912 (in Chinese).

Vorosmarty, C. J. and McIntyre P. B., et al. (2010) Global threats to human water security and river biodiversity. Nature 467, 555-561.

Ye, Q. D. and Yi, H. (2000) The frame work of risk analysis on the Chinese securities markets. Journal of Financial Research, (6), 65-79 (in Chinese).

Zhang, S. F. and Meng, X. J., et al. (2011) Water Shortage Risk Assessment in the Haihe River Basin, China. Journal of Resources and Ecology 2(4), 362-369. 